\section{AJHSE Vol: 1 (1): 81-89, 2020}

Article Ref. No.: AJHSE-0101-06

Accepted Date: Jan. 02, 2020

(C) 2020. CC License 4.0

www.ajhse.org

CrossMark

$\leftarrow$ click for updates
African Journal of Health, Safety and Environment

An official publication of the

Applied Environmental Bioscience and Public Health Research Group

University of Benin, Benin City, Nigeria

Open Access | Bi-annual | Peer-reviewed | International

ISSN (Online): 2695-1819 | ISSN (Print): 2695-2386

\title{
ASSESSMENT OF IMPACT OF A GAS PLANT ON THE ENVIRONMENT OF OGBA/EGBEMA/NDONI, RIVERS STATE, NIGERIA
}

\author{
*Odunze, W. C. \\ *Department of Environmental Management Technology, Imo State Polytechnic, Umuagwo Imo State, Nigeria \\ Phone: +2348036693530, +2348183367424 Email: drmrswisdomodunze@gmail.com
}

\begin{abstract}

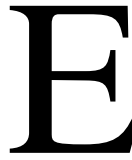

nvironmental impact of oil industries has constituted great hazard. This paper therefore evaluates the impact of gas flaring in Ogba /Egbema/Ndoni on the socio -economic well-being, environment, and health status of the inhabitants and the effort by the Industry to alleviate these effects. Mitigative measures and more effective management options were recommended. The research adopted analytical and survey research design methods. The data were obtained from questionnaire, interview and personal observation. 200 copies of structured questionnaires, were administered, while 192 were retrieved. The result showed that the gas flaring of the Industry impacted negatively from environmental to health status and socio-economic well-being, through constant rise in temperature and sooth pollution which in turn affect the agricultural produce both in quality and quantity. Cough, catarrh, skin and other respiratory diseases are associated with the activities of the oil industries in the area. The degradation of the environment weakened the economic life of the people as they depend on the agricultural yield for their income. Finally, recommendation on the need for public awareness on any project and engagement on the potential benefits of the project and abatement methods of the impact to the environment. Government to draw a line between technical and political decision as to guide office holders also Community Development Commission (CDC) staff should develop project initiative to reinforce the assessment and awareness on environmental sustenance. Health facilities to be improved and resistant species be given to farmers.
\end{abstract}

Keywords: environmental impact, health status, mitigative measures, socio-economic, oil industry

LICENSE: This article by African Journal of Health, Safety and Environment (AJHSE)is licensed and published under the Creative Commons Attribution License 4.0 International License, which permits unrestricted use, distribution, and reproduction in any medium, provided this article is duly cited.

COPYRIGHT: The Author(s) completely retain the copyright of this published article.

OPEN ACCESS: The Author(s) approves that this article remains permanently online in the open access (OA) mode.

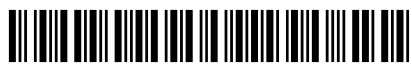

QA: This Article is published in line with "COPE (Committee on Publication Ethics) and PIE (Publication Integrity \& Ethics)". 


\section{INTRODUCTION}

The Ogba people are situated extreme south -west of Igbo land in modern Rivers State of Nigeria. They occupy an area of $600 \mathrm{~km}$ in the Niger flood plain and have combined population of 280,000 people (Francis 2016). It is located in the central Orashi Sombrero plain of Rivers State. Nigeria is one of the major producers of crude oil and gas. According oil company records, there is no local government in Nigeria that produces as much crude oil and gas as Ogba/Egbema/Ndoni local government area (Ellah, 1995).

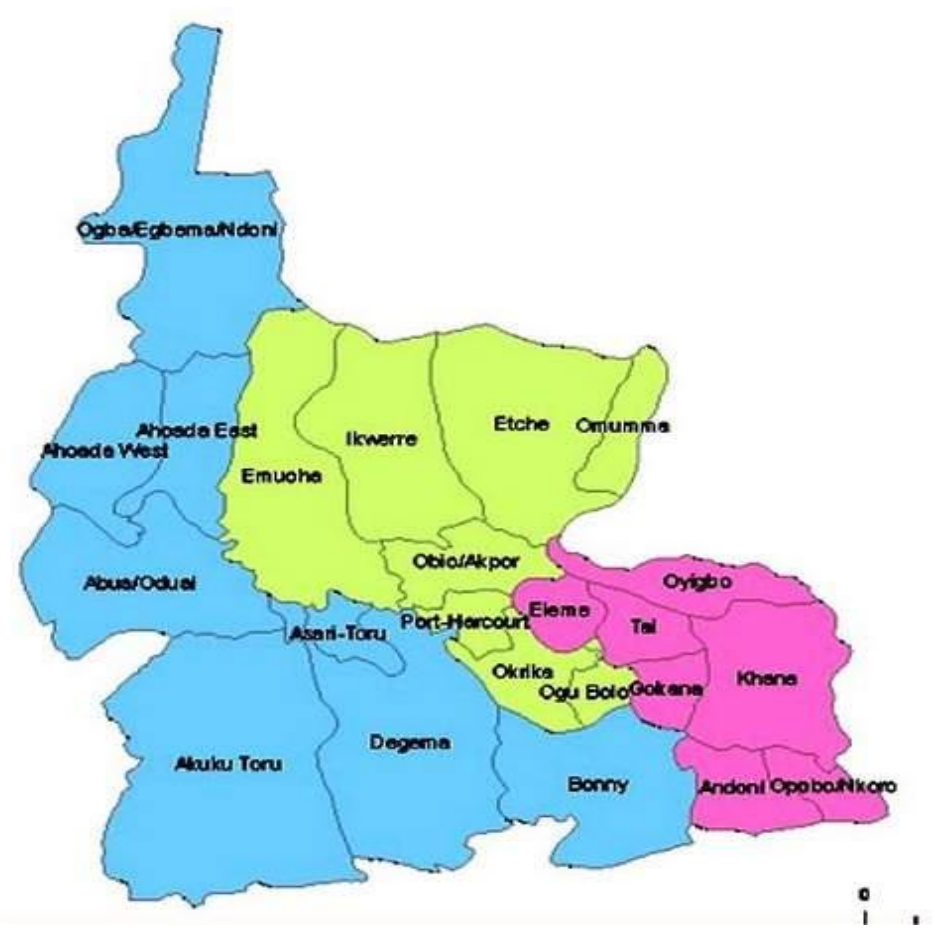

Figure 1: Source: Field work 2017

Rivers State map showing the Location of Ogba/Egbema/Ndoni Local Government Area of Rivers State.

Ogba/Egbema/Ndoni Local Government is oil Local Government in Rivers State. Natural gas is the most important natural resource that has been discovered. Environmental problems in Ogba/Egbema/Ndoni are now recognized as the key concerns for the sustainable development of the state and country at large. According to oil company records, there is no Local Government in Nigeria that produces as much crude oil and gas as Ogba/Egbema/Ndoni Local Government Area (Ellah, 1995).

The activity of oil industry in Ogba Kingdom has undergone significant environmental changes. The process involves combustion of fossil fuels that contains nitrogen oxides and sulphur dioxide which contribute atmospheric Green House Gases (GHGs) that lead to acid rains. (Iyorakpo and Odibikuma, 2015), noted that Ogba/Egbema/Ndoni area is heavily polluted with various pollutants ranging from acid rain, carbon monoxides, heavy metals and lead 
compounds. The research questions therefore go to find out the impact of the activities of the oil producing industries on the health, socio- economic life, the habitants and the environment of Ogba/Egbema/ Ndoni Local Government Area of Rivers State.

The extent of the implementation of the Environmental Impact Assessment (EIA) which is a process by which a proposed activity with potentially significant environmental, social and economic costs is studied with a view to evaluate its impacts, examining alternative approaches and developing measures to prevent or mitigate the negative impacts (Donald et al; 2002). Nigeria joined in league of EIA nations in 1992 following the enactment of its Environmental Impact Assessment Act (Decree No 84). This Act requires the completion of EIAs before a variety of project can proceed.

The impacted variables include, leakage, corrosion, staining and cracking on building, human heath low agricultural produce, poverty and even death. The study looked into the effect of non-implementation of Environmental Impact Assessment. In the past, several incidents and fatality have been recorded in host communities. Therefore, this paper aims to assess the Environmental Impact of the gas plant in Ogba/Egbema/ Ndoni on the habitats and to determine the effect of Health Impact of gaseous emission to the environment. Also, to what extent the project has impacted on the environment and to identify the effect of gas flaring on the socio-economic life of the environment. Consequently, recommend the mitigating measures and more effective management options to alleviate observed impacts.

\section{Hypotheses 1}

$\mathrm{H}_{\mathrm{o}}$ : There is no significant relationship between the Environmental Impact of Oil Industry to Socio-economic life in Ogba/Egbema/Ndoni Local Government Area of Rivers State.

\section{Hypothesis 2}

$\mathrm{H}_{\mathrm{o}}$ : There is no significant relationship between the Environmental Impact of the Oil Company to Health Status.

\section{Hypothesis 3}

$\mathrm{H}_{\mathrm{o}}$ : There is no significant effort made by Oil Industry to end gas flaring in Ogba/Egbema/Ndoni Local Government Area of Rivers State.

\section{MATERIALS AND METHODS}

This paper adopted analytical and survey research design method. The data were obtained from questionnaire and interviews. A sample of 200 questionnaires were administered, 192 retrieved and 8 were not properly filled and were discarded. The views and opinions of the inhabitants concerning the impact of the activities of the oil industries were drawn from the questionnaire. Chi-square was used as the statistical tool. Frequency counts and determination of sample size/sample techniques were equally used in the analysis of data. 


\section{RESULT}

\section{DATA PRESENTATION AND ANALYSIS}

This data presentation and analysis of the findings from the survey conducted on 192 persons, which includes farmers, traders, civil servant and students. 200 copies of the questionnaires were distributed; however, 192 copies were properly filled and returned.

Table 1: Age Occupational Status of Respondent

\begin{tabular}{llllll}
\hline & & \multicolumn{3}{c}{ Occupation } & \\
AGE & FARMERS & RADERS & CIVIL SERVANT & STUDENTS & TOTAL \\
$16-25$ & 9 & 10 & 7 & 14 & 40 \\
$26-35$ & 28 & 32 & 5 & 3 & 68 \\
$36-45$ & 23 & 8 & 10 & 1 & 42 \\
$46-55$ & 10 & 12 & 5 & 1 & 28 \\
$56 \&$ above & 3 & 7 & 3 & 1 & 14 \\
TOTAL & $\mathbf{7 3}$ & $\mathbf{6 9}$ & $\mathbf{3 0}$ & $\mathbf{2 0}$ & $\mathbf{1 9 2}$ \\
\hline
\end{tabular}

Table 1 above shows that majority of the respondents are farmers. This is not surprising as the people of the Ogba/Egbema/Ndoni Local Government Area are predominantly farmers.

Table 2: Sex of Respondent

\begin{tabular}{llllll}
\hline Sex & Farmers & Traders & Civil servants & Students & Total \\
Male & 26 & 35 & 15 & 8 & 84 \\
Female & 47 & 34 & 15 & 12 & 108 \\
Total & 73 & 69 & 30 & 20 & 192 \\
& & & & & \\
\hline
\end{tabular}

Table 2 above shows that the number of females is higher than their male counterpart. This indicates that the women in Ogba/Egbema/Ndoni were interested in the survey than the men.

Table 3: Educational Status of Respondent

\begin{tabular}{llllll}
\hline $\begin{array}{l}\text { Educational } \\
\text { Qualification }\end{array}$ & Farmers & Traders & Civil servants & Students & Total \\
B.Sc. & 10 & 28 & 24 & 1 & 63 \\
OND & 7 & 11 & 2 & 2 & 22 \\
Others & 56 & 30 & 4 & 17 & 17 \\
Total & 73 & 69 & 30 & 20 & 192 \\
\hline
\end{tabular}

Table 3 shows that majority of the Respondents who are farmers are neither Degree holder nor OND holders. 


\section{Test of Hypothesis 1}

Table 4: Do you agree that there is significant relationship between the Environmental Impact of the Oil Company to Socio-economic life in Ogba/Egbema/Ndoni Local Government Area of Rivers State?

Table 4: Impact on The Socio - Economic Life.

\begin{tabular}{llllll}
\hline & Farmers & Traders & Civil servants & Students & Total \\
Yes & $47(39)$ & $34(25)$ & $15(17)$ & $12(11)$ & 108 \\
No & $26(32)$ & $35(28)$ & $15(10)$ & $8(9)$ & 84 \\
Total & 73 & 69 & 30 & 20 & 192 \\
\hline
\end{tabular}

Table 4 indicates that more Respondent is in agreement that there is significant relationship between the Environmental Impact of the Oil Company to Socio-economic life in Ogba/Egbema/Ndoni local government area of Rivers State. Adopting chi square technique to evaluate Table 4.

$$
\mathrm{x}^{2}=\quad \sum_{i=i}^{n}(o i-E i)^{2}
$$

Therefore, $X^{2}$ calculation $=4.1$, this value will be compared with the tabulated $X^{2}$ at 0.05

The degree of freedom $(\mathrm{df})=(\mathrm{r}-1)(\mathrm{c}-1)(4-1)(2-1)$ at 0.05

$3 \times 1=3$

$=7.81$

Decision: Since the value of $x^{2}$ calculated $=9.4>$ (greater than) the $\mathrm{X}^{2}$ tab (7.81) we accept the $\mathrm{H}_{\mathrm{i}}$ (alternative) and reject the $\mathrm{H}_{\mathrm{o}}$ (null hypotheses). We therefore conclude that there is significant relationship between the Environmental Impact of the Oil servicing Company to Socio economic life in Ogba/Egbema/Ndoni local government area of Rivers State.

\section{Test of Hypotheses 2.}

Do you agree that there is any effect of the of Environmental Impact by the Oil Company on the health status of Ogba/Egbema/Ndoni? 
Table 5: Impact on the Health Status

\begin{tabular}{llllll}
\hline & Farmers & Traders & Civil servants & Students & Total \\
Yes & $58(49)$ & $60(52)$ & $25(19)$ & $16(11)$ & 159 \\
No & $15(11)$ & $9(5)$ & $5(5)$ & $4(3)$ & 33 \\
Total & 73 & 69 & 30 & 20 & 192 \\
\hline
\end{tabular}

The data in Table 5 is tested for the purpose of drawing a conclusion on hypothesis ii.

Evaluate Table 5, chi square technique is adopted.

$$
\mathrm{x}^{2}=\sum_{i=i}^{n}(o i-E i)^{2}
$$

$\mathrm{X}^{2}=1.4+1.1+1.4+1.5+1.2+1.3+0+0.3=8.2$

Therefore, $\mathrm{X}^{2}$ calculation, which is 1.8 , will be compared with the tabulated $\mathrm{X}^{2}$ at 0.05 , the degree of freedom $(\mathrm{df})=$ $(\mathrm{r}-1)(\mathrm{c}-1)$

$(4-1)(2-1)$

$3 \times 1=3$ at 0.05

$=7.81$

Decision: Since the value of $\mathrm{X}^{2}$ calculated $=8.2>$ (greater than) the $\mathrm{X}^{2}$ tab (7.81). We reject the $\mathrm{H}_{\mathrm{o}}$ (null hypotheses) and accept the $\mathrm{H}_{\mathrm{i}}$ (alternative). We therefore, conclude that there is significant relationship between the Environmental Impact of Oil Company to Health status.

\section{Test of Hypothesis 3}

Table 6: Do you agree that there is no significant effort made by the Oil Industry to end gas flaring in Ogba/Egbema/Ndoni Local Government Area of Rivers State.

Table 6: Effort to end Gas Flaring by the Oil Industry

\begin{tabular}{llllll}
\hline & Farmers & Traders & Civil servants & Students & Total \\
Yes & $50(52)$ & $55(49)$ & $20(21)$ & $12(14)$ & 134 \\
No & $15(12)$ & $9(11)$ & $3(5)$ & $4(3)$ & 31 \\
No idea & $8(9)$ & $5(9)$ & $7(4)$ & $4(3)$ & 24 \\
Total & 73 & 69 & 30 & 20 & 192 \\
\hline
\end{tabular}

Table 6 suggests that majority believes that the Oil Industry is doing nothing to reduce the gas flaring in Ogba/Egbeme/Ndoni Local Government Area of State. However, testing hypotheses III based on the data as presented on the Table 6. 
Evaluating table 4.6 Chi square technique:

$$
\mathrm{x}^{2}=\sum_{i=i}^{n}(o i-E i)^{2}
$$

$\mathrm{X}^{2}$ calculation $=0.1+0.7+0.0+0.3+0.8+0.3+0.8+0.3+0.1+1.7+2.3+0.3=7.7$

Therefore, $X^{2}$ calculated $=7.7$, this value will be compared with the tabulated $X^{2}$ at 0.05 . The degree of freedom (df) $=(\mathrm{r}-1)(\mathrm{c}-1)$

(4-1) (3-1) at $0.053 \times 2=6$

$=12.59$

Decision: Since the value of $X^{2}$ calculated $=7.7<$ (less than) $X^{2}$ tabulated (12.59) we accept the $H_{O}$ (null hypothesis) and reject the $\mathrm{H}_{\mathrm{i}}$ (alternative). We therefore conclude that there is no significant effort made Oil Industry to end gas flaring in Ogba/Egbema/Ndoni Local Government Area of River State.

\section{DISCUSSION}

The hypothesis tested in this research work showed positive and negative relationship between the variables of interest. The first hypothesis which was tested with chi-square calculation $\mathrm{X}^{2}$ value of (9.4) shows that there is significant relationship between the Environmental Impact to Socio-economic live in Ogba/Egbema/Ndoni Local Government Area of Rivers State. From the Tables 4, it is shown that the number of females were higher than their male counterpart. This is so because majority of the respondent were farmers and Ogba people are predominantly farmers. The activities of oil and in Ogba land has led to low productivity of farm land, increased communal clashes, killing and decreased in agricultural livelihood, income and poverty.

The second hypothesis tested with chi-square calculation gave the value of (8.2) which shows that there is significant relationship between the Environmental Impact of the Oil Industry to the Health Status of the people of Ogba/Egbema/Ndoni. The oil and gas development has variety of environmental impact, the effect can range from most immediate effects on the biophysical environment (land degradation and water pollution) to the more remote effects of the human environment ( such as the displacement of local inhabitants of the area where the project take place), skin rashes, sun burns. Highly concentrated industrial activities in a location are accompanied by some diseases and ailments which include; cough and catarrh, skin related diseases, respiratory problem, cancer etc.

The third hypothesis test with chi-square gave the value of (7.7) of $X^{2}$ calculated. This shows that there is no significant effort made by the Oil Industry to mitigate gas flaring in Ogba/Egbema/Ndoni Local Government Area of Rivers State. Oil and Gas companies flare gases in many parts of Rivers State which has done a great deal of environmental devastation such as acid rain on vegetation and water bodies and has increased soil $\mathrm{p}^{\mathrm{H}}$ level which then affects crop yield. These effects are from combustion of fossils fuels that contains nitrogen oxide and Sulphur oxide that contribute to atmospheric Green House Gases (GHG) that led to acid rain. The sooth which has been an issue of concern to the state were not left out. The impact variables include corrosion leakage, staining and cracking on building/structure, retracts, movement, human health among others, (Echefu, and Akpofure, 2013). The gas flare raises the temperature of the surrounding to about 13-14000 degree Celsius and causes noise pollution around vicinity 
of the flare. Another problem associated with gas flaring is light pollution which subjects the living organisms around the vicinity of the flare to 24hours daylight (Dadiowe, 2009). This greater hit is on the close proximity which is residence closer to the source of emission.

\section{CONCLUSION}

This study has exposed the importance of assessment of Environmental Impact of any project especially oil Industry to determine the significant effect on the environmental, socio-economic and health status and consequently follow up with mitigative measures by the host community and the Government.

Therefore, the purpose of this study were limited to; assessment of the Environmental Impact of the gas plant in Ogba/Egbema/Ndoni Local Government on the habitats, the effect of health impact of gaseous emission to the environment, the extent the project has impacted on the environment, the effect of gas flaring on the socio-economic life of the environment rather recommendations on the mitigative measures and more effective management options to alleviate the observed impacts.

It is vital to note that pre and post Environmental Impact Assessment is a tool for carrying out every project in the state, whether non - oil production or oil production project. And the community involvement in pre and post assessment process will mitigate communal problem within the host communities.

This study has shown the devastating effect of gas plant to host community such as low productivity of farm products and long-term effect of hydrocarbons in the body system that causes health challenges. The greater hit is on close proximity, which is residence closer to the source of emissions

\section{REFERENCES}

Allen, I. and Chilenye, N. (2014); Environmental Impact Assessment process for Oil, Gas and Mining Projects in Nigeria. A critical Analysis, Law Environment and Development $3^{\text {rd }}$ Edition pp 35. Switzerland; Haniel Pushlishers.

Alam, J.B., Almel, A.A.M and Munna, G.M, (2010). Environmental Impact Assessment of Oil and Gas Sector. A Case Study of Magurchara Gas Field. Journal of Soil source and Environmental Management 5(9): $117-121$.

Donald, N.Z, Alastair R.L, and George P (2002); Public Participation in the Sustainable Development of Mining and Energy Resources, $6^{\text {th }}$ Edition, pp38, New York Oxford University Press.

Dadiowe. T. (2009); Environmental Impact Assessment and Sustainable Development in the Niger $\quad$ Delta ppin the Gambian oil field experience, Niger Delta Economic of violence.

Decree No 86 of 1992 (1992) EIA Act. Environmental Impact Assessment in Nigeria and Regulatory Background and Procedural Framework, Nigeria.

Echefu. N. and Akpofure. E, (2013); Human Right in National Resource Development. Institute of International Studies Journal 9(24) $79-85$

Elleh, Francis J, (1995) Ali-Ogba, A history of Ogba people, 2nd Edition, pp 27- 63, Port Harcourt, Ziklag publishers

Iyarakpo, J and Odibikuma, P.W. (2015), Impact of Gas Flaring on the Built Environment. The case of Ogba/Egbema/Ndoni Local Government Area, Rivers State, Nigeria. European scientific Journal,11 No (26) 46-63 